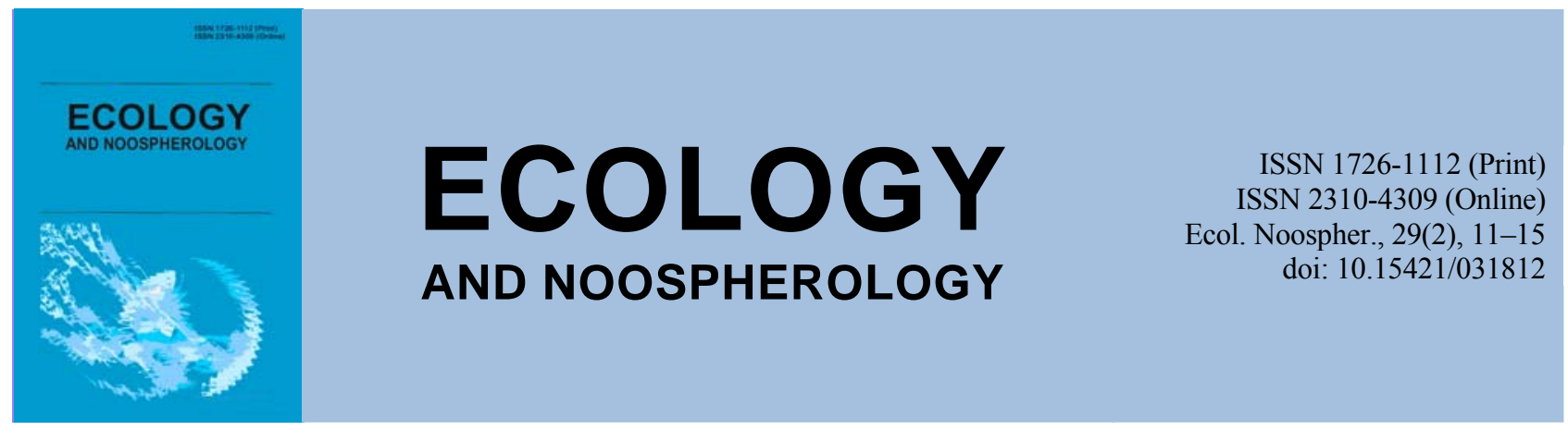

\title{
Ecological features of enzyme activity distribution in edaphotops of technogenic landscapes
}

\author{
V. I. Chorna, I. V. Wagner, V. V. Katsevych \\ Dniprovsk State Agrarian and Economic University, Dnipro, Ukraine
}

Article info

Received 15.10.2018

Received in revised form

22.10 .2018

Accepted 27.10.2018

Dniprovsk State Agrarian and Economic University,

str. Serhiy Yefremov, 25, Dnipro, 49000, Ukraine.

Tel.: +38-097-268-38-71

E-mail:v.ch.49a@gmail.com
Chorna, V. I., Wagner, I. V., \& Katsevych, V. V. (2018). Ecological features of enzyme activity distribution in edaphotops of technogenic landscapes. Ecology and Noospherology, 29(2), 11-15. doi:10.15421/031812

Specific features of distribution total, available phosphorus concentrations and levels of phosphatase enzymatic activity at the layers of artificial soil, sod-lithogenic soils onto gray-green and red-brown clays and on loess-like loams in the Nikopol manganese ore basin are established. It is presented general assessment of technosoil status by evaluation of phosphatase enzyme activity; this enzyme enriches the soil with mineral phosphorus and thereby improves its availability for living organisms. Among current bioindication methodology, soil enzymatic method is the most reliable and promising because enzymatic activity serves a stable indicator of soil biogenicity in comparison with other indicators. Soil enzymatic activity determines both intensity and targeting of biogeochemical processes. High correlation between concentrations of soluble phosphorus and phosphatase activity values by layers of artificial soil $(\mathrm{r}=0.87)$, sod-lithogenic soils onto gray-green $(r=0.77)$, red-brown clays $(r=0.62)$ and onto loess-like loam $(r=0.95)$ was determined. Tendency of decreasing hydrolytic enzyme activity, phosphatase, with depth in all types of artificial soil studied was established. High efficiency of the enzymatic activity study in diagnostics of soil fertility dynamics under impact of various anthropogenic and natural ecosystems was determined. Advantages of using this method are capability to determine rapidly the changes occurring in ecosystems in the early stages of degradation processes and prediction of their targeting and, accordingly, their intensity. It has been found that levels of phosphatase activity and values of mobile phosphorus compounds in complex biogeocoenotic systems are sensitive quantitative indicators of changes in environmental conditions in man-made environment, and they generate good data about processes occurred within the soil column. The use of phosphatase activity level can be a reliable and promising method on biomonitoring of technogenic edaphotops.

Keywords: reclamation; technosol; soil enzymes; phosphatase

\section{Екологічні особливості ферментативої активності едафотопів техногенних ландшафтів}

\author{
В. І. Чорна, І. В. Вагнер, В. В. Кацевич
}

Дніпровський державний аграрно-економічний університет, Дніпро, Украӥна

Визначено особливості розподілу концентрації загального рухомого фосфору і рівней ферментативної активності фосфатази по шарах педоземів, дерново-літогенних грунтів на сіро-зелених і червоно-бурих глинах та на лесоподібних суглинках Нікопольського марганцеворудного басейну. Представлено загальну оцінку стану техноземів за активністю гідролітичного ферменту фосфатази, яка збагачує грунт мінеральним фосфором і таким чином поліпшує забезпеченість ним живих організмів у доступній формі. Установлено високу кореляційну залежність між концентрацією розчинного фосфору $і$ рівнем активності грунтової фосфатази по шарах педоземів $(\mathrm{r}=0,87)$, дерново-літогенних грунтів на сіро-зелених $(\mathrm{r}=0,77) \mathrm{i}$ червоно-бурих глинах $(\mathrm{r}=0,62)$ та лесоподібних суглинках $(\mathrm{r}=0,95)$. Установлено, що рівень фосфатазної активності і вміст рухомих сполук фосфору складних біогеоценотичних систем $€$ чутливим кількісним показником на зміни екологічних умов техногенного середовища і надає реальні уявлення про процеси, які відбуваються в товщі едафотопів. Використання рівня 
фосфатазної активності може бути надійним і перспективним напрямом біомоніторингу едафотопів техногенно-порушених ландшафтів.

Ключові слова: рекультивація; техноземи; грунтові ферменти; фосфатаза

\section{Вступ}

Техногенне навантаження та довготривале добування корисних копалин в Україні призвело до значних змін довкілля та перетворення природних компонентів у природно-техногенні. Найбільш доцільним 3 екологічної точки зору $\epsilon$ відновлення порушених земель шляхом рекультивації (Demidov et al., 2013; Wagner, Chorna, 2017).

Рекультивація земель передбачає антропічне формування педоземів (едафотоп 3 насипним родючим шаром грунту) i літоземів (складені нетоксичними геологічними породами пізнього пліоцен-плейстоценового періоду: лесоподібні суглинки, червоно-бура, сіро-зелена глина тощо) (Voloch, Uzbek, 2010).

Зональні чорноземи, як біологічне тіло природи, є продуктом тривалої тісної взаємодії абіотичних та біотичних чинників на материнську породу. Функціональну залежність між чинниками грунтогенезу, їх речовинно-енергетичний вплив на материнську породу можливо досліджувати в сучасних умовах на рекультивованих літоземах 3 урахуванням природної еволюції самозаростання винесених на поверхню порід та антропогенно спрямованого фітомеліоративного фактора (Voloch, 2010; Loza, Chorna, 2017; Katsevych, Gritsan, 2018).

Важливим фактором грунтоутворення є ферментативна активність грунтів. Важливу роль у формуванні грунтової родючості відіграють грунтові ферменти (Gonchar, 2006), які каталізують багаточисельні реакції перетворення органічної речовини грунту: гідроліз, розщеплення, окиснення та інші реакції, у результаті яких грунти збагачуються доступними для рослин і мікроорганізмів поживними речовинами (Shvakova, 2013). Ферменти - це обов'язкова частина біологічної складової грунту. Головні джерела грунтових ферментів - грунтові мікроорганізми, у меншій мірі - корені рослин і грунтові тварини. Грунт характеризується певним рівнем ферментативної активності, яка обумовлена вмістом ферментів (Sardar, 2007). Ферменти характеризуються строгою специфічністю дії і високою активністю, яка залежить від багатьох факторів: температури, вологості, рН грунту, кількості гумусу, мінерального складу, фізико-хімічних і біологічних показників грунту, вмісту інгібіторів ферментів, органічної речовини як поживного субстрату для мікроорганізмів (Svakova, 2013; Gonchar, 2006).

Серед існуючих методів біоіндикації грунтів ферментативний метод $\epsilon$ найбільш надійним та перспективним, оскільки активність ферментів порівняно 3 іншими показниками слугує стійким показником біогенності грунтів (Gonchar, 2012). Ферментативна активність грунтів визначає інтенсивність і спрямованість біохімічних процесів, від яких залежить родючість грунту. Фосфатаза забезпечує грунт мінеральним фосфором і тим самим підвищує забезпеченість ним живих організмів у доступній формі.

Метою досліджень було вивчення особливостей розподілення активності фосфатази, загального i доступного фосфору у профілях техноземів - педоземі, дерново-літогенних грунтах на сіро-зелених i червонобурих глинах та на лесоподібному суглинку Нікопольського марганцеворудного басейну (м. Покров).

\section{Матеріали та методи досліджень}

Дослідження активності фосфатази, загального i доступного фосфору проводили в науково-дослідній лабораторії гідроекології Дніпровського державного аграрно-економічного університету. Зразки відбирали на дослідних ділянках науково-дослідного стаціонару 3 рекультивації земель Дніпровського державного аграрноекономічного університету (м. Покров, Дніпропетровська область) (Demidov et al., 2013; Tarika, 2006; Matychenkov, 2012), із закладанням грунтових розрізів з названих типів техноземів. Проби відбирали по шарах 0-10, 10-20 ... 90100 см у триразовій повторюваності. Активність фосфатази вимірювали методом Haziev (2005), AcostaMartinez (2007). Для визначення активних форм фосфору i загального вмісту фосфору у грунтах використовували метод Kirsanova у модифікації ЦІАНО.

Статистичну обробку одержаних результатів проведено за допомогою програми Statistica 7.0.

\section{Результати та їх обговорення}

Експериментальні дані 3 визначення концентрації загального фосфору представлені в табл. 1 .

Аналізуючи отримані результати, слід відзначити, що в педоземах валовий вміст фосфору змінюється за профілем $\mathrm{i}$ має максимальне значення в орному шарі $(1,364$ г/кг) 3 наступним зниженням у шарах 60-70 см на $45 \%$. У техноземі на лесоподібних суглинках встановлено збільшення концентрації загального фосфору починаючи 3 глибини 30-40 см. У дерново-літогенних грунтах на червоно-бурих глинах в орному та підорному шарах спостерігається постійний вміст загального фосфору 3 незначним підвищенням на $10 \%$ у шарах 60-90 см. У техноземах на сіро-зелених глинах валовий вміст фосфору в орному шарі має значення 0,931 г/кг, потім зменшується, а на глибині 70-90 см зростає на $40 \%$ відносно шару 0-10 см.

\section{Таблиця 1}

Вміст загального фосфору в дерново-літогенних грунтах на червоно-бурих глинах, педоземах, сіро-зелених глинах і лесоподібних суглинках за профілем $(\mathrm{M} \pm \mathrm{m})$

\begin{tabular}{ccccc}
\hline \multirow{2}{*}{ Шар грунту, см } & \multicolumn{3}{c}{ Вміст загального фосфору в техноземах, г/кг } \\
\cline { 2 - 5 } & на педоземах & $\begin{array}{c}\text { на лесоподібних } \\
\text { суглинках }\end{array}$ & $\begin{array}{c}\text { на червоно-бурих } \\
\text { глинах }\end{array}$ & $\begin{array}{c}\text { на сіро-зелених } \\
\text { глинах }\end{array}$ \\
\hline $0-10$ & $1,364 \pm 0,119$ & $0,739 \pm 0,071$ & $0,617 \pm 0,059$ & $0,921 \pm 0,087$ \\
$10-20$ & $0,946 \pm 0,084$ & $0,695 \pm 0,063$ & $0,616 \pm 0,060$ & $0,528 \pm 0,51$ \\
$20-30$ & $0,922 \pm 0,089$ & $0,659 \pm 0,069$ & $0,614 \pm 0,058$ & $0,327 \pm 0,033$ \\
$30-40$ & $0,901 \pm 0,090$ & $1,125 \pm 0,111$ & $0,408 \pm 0,039$ & $0,516 \pm 0,050$ \\
$40-50$ & $0,876 \pm 0,079$ & $1,023 \pm 0,101$ & $0,667 \pm 0,061$ & $0,698 \pm 0,063$ \\
$50-60$ & $0,745 \pm 0,069$ & $1,134 \pm 0,111$ & $0,617 \pm 0,059$ & $0,674 \pm 0,064$ \\
$60-70$ & $0,734 \pm 0,070$ & $1,111 \pm 0,099$ & $0,685 \pm 0,064$ & $0,611 \pm 0,059$ \\
$70-80$ & $0,875 \pm 0,074$ & $1,200 \pm 0,118$ & $0,664 \pm 0,065$ & $1,140 \pm 0,111$ \\
$80-90$ & $0,943 \pm 0,090$ & $1,156 \pm 0,116$ & $0,725 \pm 0,071$ & $1,304 \pm 0,122$ \\
\hline
\end{tabular}


За даними I. В. Матиченкова (Matychenkov, 2012), вміст фосфору в нижніх горизонтах значно менший, ніж у верхніх. Відомо, що значна частина фосфору знаходиться в грунті у вигляді фосфор-органічних сполук. Збільшення вмісту фосфору у нижніх горизонтах деяких грунтів безпосередньо пов'язане зі складом гірських порід.

Аналізуючи дані вмісту розчиненого фосфору за профілем чотирьох типів рекультоземів (рис. 1), слід відмітити, що найбільший рівень концентрації зафіксовано в орному шарі педозему, найменший - у техноземі на лесоподібному суглинку. У техноземах на червоно-бурих

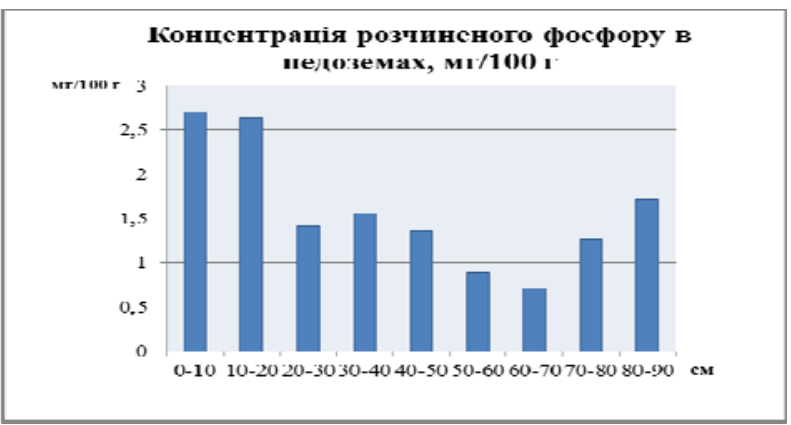

$a$

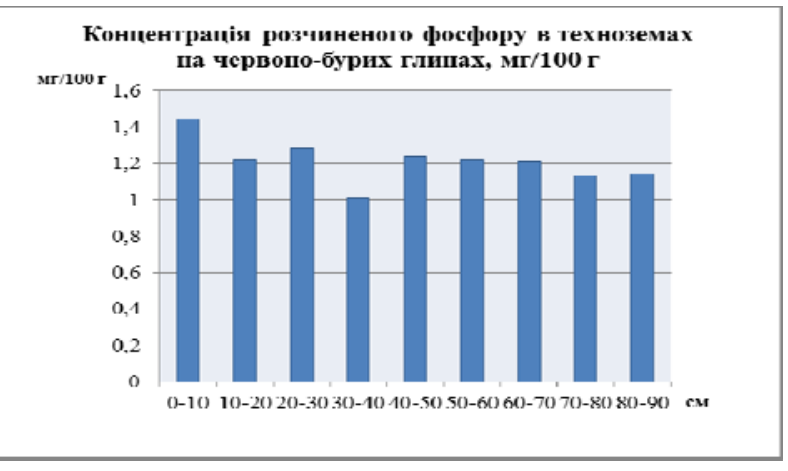

B та сіро-зелених глинах суттєвих змін доступного фосфору 3 глибиною нами не виявлено.

Оцінка грунтів за вмістом рухомих сполук фосфору залежить від типу грунтів. Відомі градації грунтів за ступенем забезпеченості рухомими формами фосфору показано в табл. 2. Рівень забезпеченості досліджуваних грунтів рухомими формами фосфору за допомогою класифікаційних градацій за Кірсановим (ГОСТ 26207-91), Чириковим (ГОСТ 26204-91) та Мачигіним (ГОСТ 26205-91) включає такі оцінки: дуже низькій, середній, підвищений, високий, дуже високий.

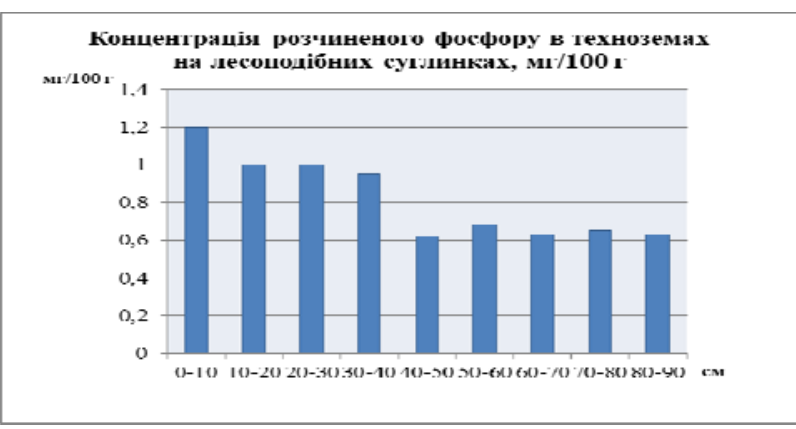

$\sigma$

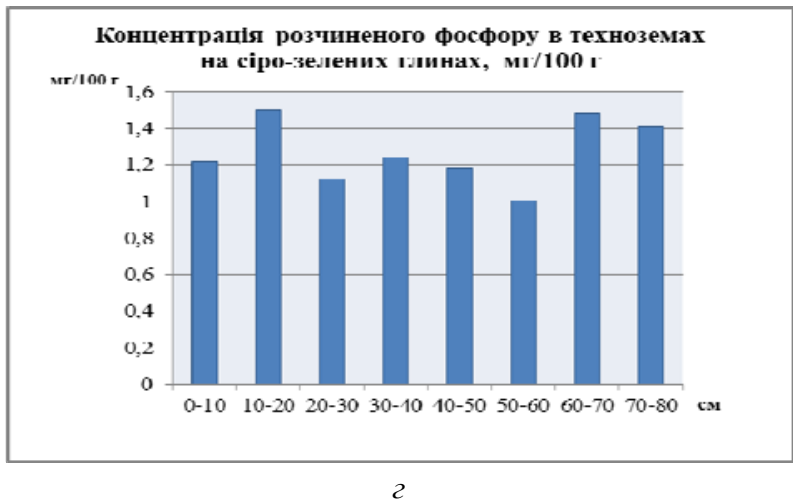

Рис. 1. Вміст розчиненого фосфору у профілі педозему ( $a$ ), технозему на лесоподібному суглинку (б), на червоно-бурій (в) та сіро-зеленій глині (2)

Таблиця 2

Класифікаційні градації грунтів за ступенем забезпеченості рухомими формами фосфору

\begin{tabular}{cccc}
\hline Ступінь забезпечення & За Кірсановим, (мг/100 г) & За Чириковим, (мг/100 г) & За Мачигіним, (мг/100 г) \\
\hline грунтів & До 2,5 & До 2 & До 1 \\
Дуже низький & $2,5-5$ & $2-5$ & $1-1,5$ \\
Низький & $5-10$ & $5-10$ & $1,5-3$ \\
Середній & $10-15$ & $10-15$ & $3-4,5$ \\
Підвищений & $15-25$ & $15-20$ & $4,5-6$ \\
Високий & $>25$ & $>20$ & $>6$ \\
Дуже високий &
\end{tabular}

Розглянувши класифікаційні градації грунтів за Кірсановим бачимо, що експериментально встановлені показники забезпеченості рухомими формами фосфору дуже низькі у всіх профілях; за Чириковим спостерігається аналогічна тенденція; за Мачигіним ступінь забезпеченості досліджуваних грунтів рухомими формами фосфору характеризується як середній.

Одним із важливих показників, що характеризують продуктивність грунтів, $€$ ферментативна активність. Дослідження в цій галузі проводились багатьма вченими (Galstyan, 1982; Shechovtsova, 2011), які визначали високу ефективність дослідження цього показника для діагностики динаміки родючості грунтів за різних антропічних i природних впливів на екосистеми. Перевагою використання цього методу $\epsilon$ можливість швидкого визначення змін, що відбуваються в екосистемах на ранніх стадіях розвитку деградаційних процесів, прогноз їх спрямованості і відповідно ступінь проявлення. Досліджуваний нами фермент відноситься до класу гідролаз, які відіграють істотну роль у гідролітичному розщепленні органічних речовин, збагачуючи грунт доступними для рослин поживними елементами. Фосфатаза бере участь у розкладанні фосфорної кислоти і мобілізації доступного рослинам фосфору.

Експериментальні дані про зміни активності фосфатази у профілях досліджуваних грунтів представлені на рис. 2.

Активність фосфатази має найбільше значення в шарах 0-10 та 10-20 см в усіх досліджуваних структурах, причому в порядку зменшення активності досліджувані грунти розташовуються в такій послідовності: педоземи, техноземи на сіро-зелених глинах, техноземи на червонобурих глинах i лесоподібних суглинках. За оцінкою 

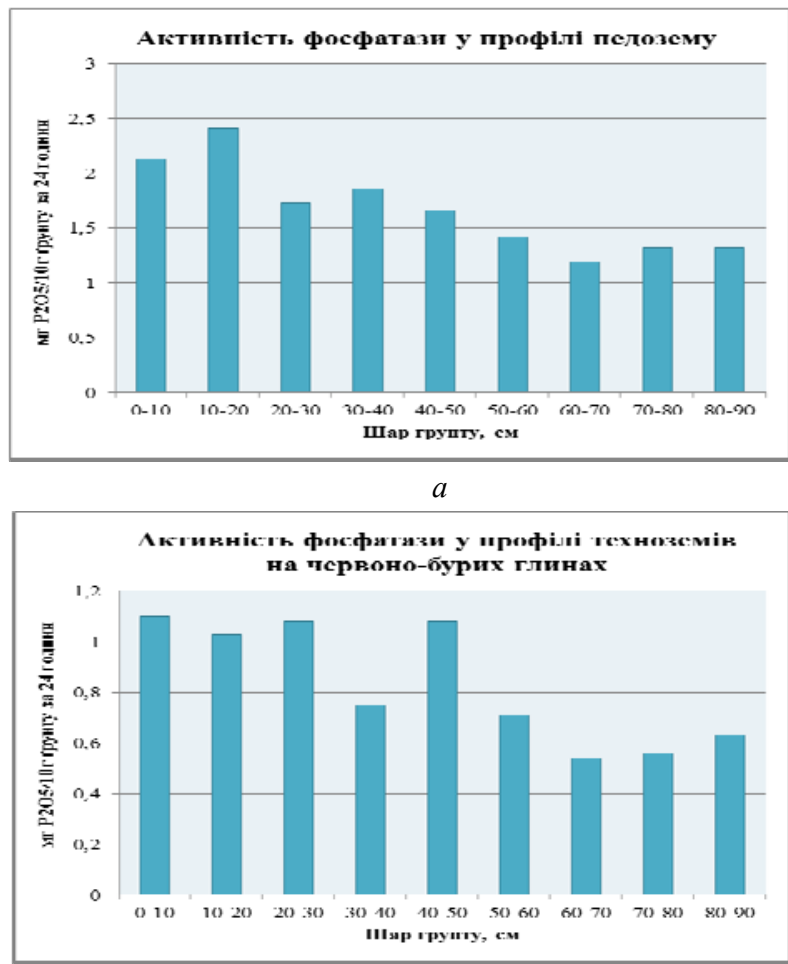

B

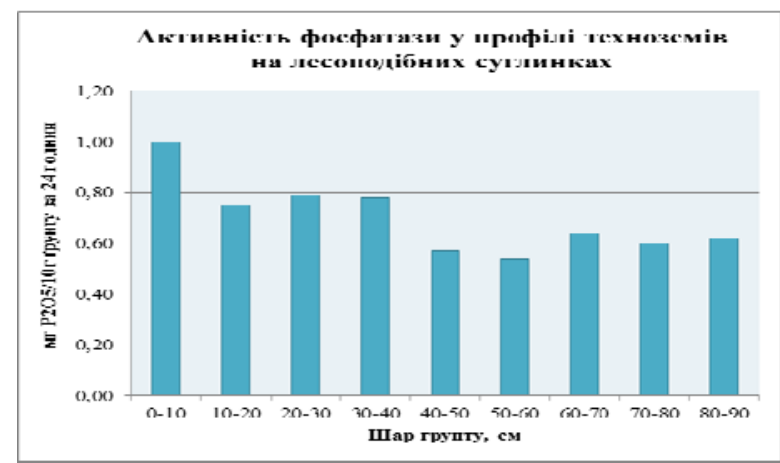

6

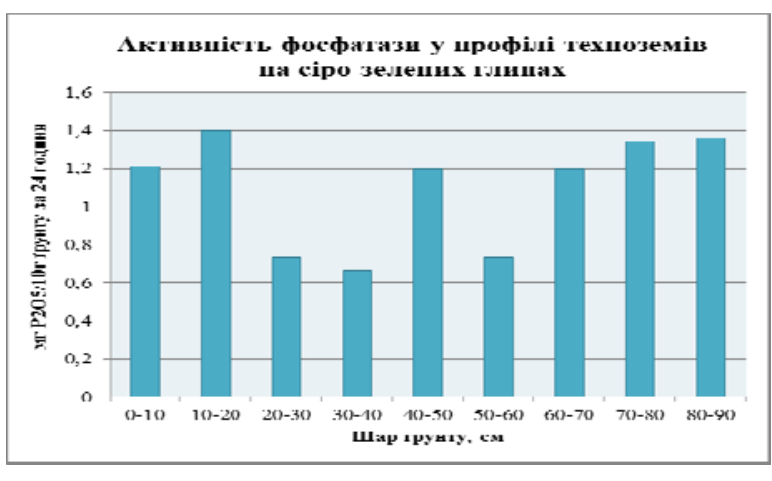

2

Рис. 2. Активність фосфатази у профілі педозему (a), технозему на лесоподібному суглинку (б), на червоно-бурій (в) та сіро-зеленій глині (2)

Козлова, грунти за ступенем забезпечення фосфатазою класифікуються як бідні в техноземах і середні - у педоземах (Kozlov, 1964). Аналізуючи залежність активності фосфатази по шарах педозему та дерноволітогенних грунтів на сіро-зелених, червоно-бурих глинах та лесоподібному суглинку, слід відмітити тенденцію зниження активності 3 глибиною. Установлено пряму залежність активності фосфатази та концентрації рухомого фосфору 3 коефіцієнтом кореляції 0,87 , що характеризується як високий у педоземі. Відповідний коефіцієнт кореляції у профілі технозему на лесоподібному суглинку становив - 0,95 як дуже високий; на червоно-бурій глині - 0,62 за рахунок суттєвого зниження активності фосфатази у нижніх шарах технозему; на сіро-зеленій глині - 0,77.

\section{Висновки}

1. Активність фосфатази визначена в усіх шарах педоземів та дерново-літогенних грунтів на сіро-зелених та червоно-бурих глинах та лесоподібному суглинку досліджуваних профілів техноземів, але варіює за рівнем активності в залежності від глибини шару i типу технозему.

2. Установлено високу ступінь кореляційної залежності між вмістом доступного фосфору та рівнем активності фосфатази, ферментом, відповідальним за мінералізацію органічного фосфору i надходження мінерального фосфору в коріння рослин у всіх чотирьох типах грунтів $(\mathrm{r}=0,62-0,95)$

3. Установлено, що біохімічна діагностика за гідролітичним ферментом фосфатазою, що виконує деструкційну функцію, дозволяе надати оцінку інтенсивності процесу мінералізації і спрямованості змін родючості грунтів на різних типах техноземів.

4. Рівень фосфатазної активності складних біогеоценотичних систем $\epsilon$ чутливим кількісним показником на зміни екологічних умов техногенного середовища і надає реальне уявлення про процеси, що відбуваються в товщі едафотопів.
5. Використання рівня ферментативної активності $\epsilon$ надійним i перспективним напрямом біомоніторингу едафотопів техногенно порушених ландшафтів.

\section{Подяки}

Дослідження виконане за фінансової підтримки Міністерства освіти і науки України у рамках держбюджетної теми № 0117U004291 «Розробка сучасної концепції відновлення біотичного потенціалу рекультивованих земель для раціонального землевикористання».

\section{References}

Acosta - Martinez, V. (2007). Microbial communities and enzymatic activities under different management in semiarid soils. Eppl. Soil Ecol., 38, 249-260.

Demidov, A. A., Kobets, A. S., Gritsan, Yu. I., Zhukov, A. V. (2013). Prostranstvennaya agroekologiya i rekultivatsiya zemel [Spatial agroecology and land recultivatijn]. Dnepropetrovsk (in Russian).

Galstyan, A. Sh. (1982). Ob ustoychyvosty fermentov pochv [On the stability of soil enzymes]. Eurasian Soil Science, 4, 108-110 (in Russian).

Gonchar, N. V. (2006). Invertazna aktyvnist yak pokaznyk stupenya okulturenosty edafotopiv tekhnogennuch landshaftiv [Invert activity as an indicator of the degree of culturedness of edaphotops of technogenic landscapes]. Gruntoznavstvo, 7(3-4), 128-132 (in Ukrainian).

Katsevych, V. V., Hrytsan, Yu. I. (2018). Edafichna kharakterystyka dernovo-litohennykh gruntiv na siro-zelenykh hlynakh na zasadakh ekolohichnoi mikromorfolohii [Edaphic characteristics of soddy-lithogenic soil on greygreen clays on the basis of environmental micromorphology]. Visnyk Poltavskoi derzhavnoi ahrarnoi akademii. Silske hospodarstvo. Ekolohiia, 4, 131-136 (in Ukrainian).

Khaziev, F. Kh. (2005). Metody pochvennoy enzymologii [Metods of Soil Enymology]. Moscow (in Russian).

Loza, I. M., Chorna, V. I. (2017). Ekolohichne otsinyuvannya yakosti rekultyvatsiyi zemel karyeru vydobutku marhantsevoyi 
rudy shchodo mozhlyvosti isnuvannya gruntovykh bezkhrebetnykh [Environmental evaluation of suitability of recultivated land in a manganese quarry for the existence of soil biota]. Biosystems Diversity, 25(4), 318-322 (in Ukrainian).

Matychenkov, I. V. (2012). Izuchenie vzaimovliyanie kremnievyih, fosfornyih, azotnyih udobreniy v sisteme pochva-rastenie [Study on interaction of silicon, phosphorous, and nitrogen fertilizers in soil-plant system]. Avtoref. dys. na zdobuttia nauk. stupenia kand. boil. nauk. Moscow (in Russian).

Sardar, K. (2007). Soil Enymatic Activities and Microbial Community Structure with Different application rates of $\mathrm{Cd}$ and $\mathrm{Pb}$. Journal of Environmental Sciences, 19(7), 834-840.

Shechovtsova, O. G. (2011). Biologichna aktivnist urbanizovanykh gruntiv Mariupolia [Biological activity of the urbanized soils of Mariupol]. Gruntoznavstvo, 12(1-2), 88-91 (in Ukrainian).

Tarika, O. H. (2006). Ahroekolohichne obgruntuvannia osvoiennia i vykorystannia lesopodibnoho suhlynku pry rekultyvatsii zemel v Nikopolskomu marhantsevorudnomu baseini
[Agroecological substantiation of the development and use of forest loam in the reclamation of land in the Nikopol manganese ore basin]. Avtoref. dys. na zdobuttia nauk. stupenia kand. s/h nauk: spets. 03.00.16 - «Ekolohiia». Dnipropetrovsk (in Ukrainian).

Volokh, P. V., Uzbek, I. Kh. (2010). Suchasnyi hruntohenez na rekultyvovanykh litozemakh zony Stepu Ukrainy [Modern soil genesis on reclaimed lithozems of the steppe of Ukraine]. Visnyk Dnipropetrovskoho derzhavnoho ahrarnoho universytetu, 1, 39-47 (in Ukrainian).

Wagner, I. V., Chorna, V. I. (2017). Vpluv aktuvnuch form kremiyu na biomassy s/g kultur pid chas ich vuroshuvannya na technogenno-porushenuch gruntach nikopolskogoargancevorudnogo basseinu [The effect of active forms of silicon on the biomass of agricultural crops during their growth period on technogenically altered soils of the Nikopol Manganese Ore Basin]. Biosystems Diversity, 25(2), 74-82 (in Ukrainian). 